\title{
Dung beetles in a Caatinga Natural Reserve: a threatened Brazilian dry-forest with high biological value
}

\author{
Letícia Vieira' ${ }^{1}$ Fernando A. B. Silva² \& Júlio Louzada ${ }^{3}$
}

\begin{abstract}
1. Departamento de Ciências Naturais, Universidade Federal de São João del-Rei, Praça Dom Helvécio, 74, Bairro Fábricas, $36301-160$ São João del-Rei, Minas Gerais, Brazil. (leticia@ufsj.edu.br)

2. Instituto de Ciências Biológicas, Universidade Federal do Pará, Rua Augusto Corrêa, 01, 66075110 Belém, Pará, Brazil. (fernandoabsilva@yahoo.com.br) 3. Setor de Ecologia, Departamento de Biologia, Universidade Federal de Lavras, Lavras, Minas Gerais, Brazil. (jlouzada@gmail.com)
\end{abstract}

Received 12 May 2017

Accepted 24 November 2017

$10.1590 / 1678-4766 e 2017045$

\begin{abstract}
The Caatinga is an endemic and threatened dry-forest biome distributed across northern Brazil. We evaluated the conservation value of a Caatinga Natural Reserve (NR) - Floresta Nacional (FLONA) Contendas do Sincorá - using Scarabaeinae dung beetles as a biodiversity indicator Specifically, we contrasted two zones impacted by two distinct intensity of selective logging that happened inside the NR until 1997. Dung beetles were collected 14 years after logging, using baited pitfall traps within three main habitats (riparian forest, regenerating Caatinga or arboreal Caatinga) found in two zones (Preservation and Management Zones). A total of 1,214 individuals from 21 species were sampled. The two zones presented distinct species composition, although the habitats did not exhibit such differences. Our results indicated that the secondary areas are in a conservation status similar to arboreal Caatinga and riparian forest, $14 \mathrm{y}$ after logging. Furthermore, we identified seven habitat-indicator species, two of them typical to Caatinga biome, highlighting the importance of updates in NR management plan considering the Scarabaeinae regional diversity management.
\end{abstract}

KEYWORDS. Floresta Nacional Contendas do Sincorá, xerophyte vegetation, management plan, Scarabaeinae.

RESUMO. Escarabeíneos em uma Unidade de Conservação da Caatinga: uma floresta seca brasileira com alto valor biológico. A Caatinga é um bioma endêmico e ameaçado de floresta seca distribuída ao longo do Nordeste do Brasil. Nós avaliamos a importância conservacionista da unidade de conservação (UC) Floresta Nacional (FLONA) Contendas do Sincorá - utilizando besouros escarabeíneos como indicador da biodiversidade. Especificamente, nós contrastamos duas zonas com diferentes intensidades de impacto por corte seletivo que ocorreu no território da UC até 1997. Os besouros foram coletados 14 anos após o término o corte seletivo, através de armadilhas tipo pitfall iscadas, em três habitats principais da UC (mata ciliar, Caatinga em regeneração e Caatinga arbórea) encontrados em duas zonas (Zona de Preservação e de Manejo). Um total de 1.214 indivíduos de 21 espécies foi amostrados. As duas zonas apresentaram composições de espécies distintas, entretanto os habitats não apresentaram tais diferenças. Nossos resultados indicam que as áreas secundárias estão em um estado de conservação similares às de Caatinga arbórea e mata ciliar após 14 anos de corte. Além disso, nós identificamos sete espécies indicadoras de habitat, duas delas típicas do bioma da Caatinga, destacando a importância de reformulação do plano de manejo da UC considerando a manutenção da diversidade regional dos Scarabaeinae.

PALAVRAS-CHAVE. Floresta Nacional Contendas do Sincorá, vegetação xerófita, plano de manejo, Scarabaeinae.

The Caatinga, an exclusive dry biome in the Brazilian territory covering around $736.000 \mathrm{~km}^{2}$, has been receiving little attention regarding the preservation of its landscape and biota (SILva et al., 2004). It is estimated that approximately 30.4 to $51.7 \%$ of the territory has been modified by anthropic activities (LEAL et al., 2005). Among the main reasons for the loss or change of habitat quality in the Caatinga we can identify firewood cutting, hunting and the local population continuous interference in the vegetation for bovine and goat keeping (Leal et al., 2005; Ramos \& Albuquerque, 2012). In addition, the long dry periods contribute to a low agricultural production in the region (SAMPAIO \& BATISTA, 2004) demanding new areas for plantations in a short-period of time after the first production cycle. Despite the intense anthropic pressure on the Caatinga vegetation, this region has the shortest number and protected areas within the Brazilian biomes (LEAL et al., 2005), with less than $1 \%$ of its territory under the integral protection category (MMA, 2016).

Here, we used dung beetles (Coleoptera: Scarabaeidae: Scarabaeinae) as a tool to evaluate the Caatinga's ecosystems functioning and provide insights to the management of a relevant Natural Reserve (NR) - National Forest Contendas do Sincorá (FLONA Contendas do Sincorá). Through this data, we intend to provide information about dung beetles diversity in the distinct management zones proposed when the preserved was created after 14-year without any logging activity, which means 14-year of vegetation self-recovering.

We tested the hypothesis that the most preserved area inside the NR, the Preservation Zone (isolated area, with little human disturbance), support a distinct dung beetle assemblage composition contrasted to the Management Zone (it includes administrative buildings and flux of people). In 
the most preserved area, we expect to find a more Caatinga' specialized group of species, indicating the success of the recovering process after logging. Our hypothesis is supported by the fact that Scarabaeinae assemblages are highly sensitive to environmental changes (HALFFTER \& FAVILA, 1993; GARDNER et al., 2008; GrIES et al., 2012). They have also been used as useful tools to evaluate the level of conservation in natural areas, selective logging management plans and studies on global warming (BARBERo et al., 1999; VAN RENSBURG et al., 1999; DAVIS, 2002).

\section{MATERIAL AND METHODS}

Study area. The FLONA Contendas do Sincorá is an 11.034-hectare NR categorized as sustainable use (SNUC, 2000), located in Contendas do Sincorá municipality, state of Bahia. It is placed in the Caatinga northern portion of Brazilian territory and in the southern part of the Chapada Diamantina $\left(13^{\circ} 46^{\prime}-14^{\circ} 0^{\prime} \mathrm{S} 41^{\circ} 03^{\prime}-41^{\circ} 10^{\prime} \mathrm{W}\right)$. The climate is semi-arid with an average annual precipitation of 600 $\mathrm{mm}$. The rainy season ranges from November to April and humidity between 20-40\% (BRASIL, 2006).

This NR is important to the Caatinga conservation since it groups a full range of phytophysiognomy formations such as arboreal caatinga, shrubby caatinga, shrubbery forests (regenerating caatinga), vine forests (a typical transition vegetation between the Mata Atlântica and Caatinga Biomes), cerrados (Brazilian savanna) and riparian forests (BRASIL, 2006). The vegetation in the region is deciduous and xerophyte, composed mainly by shrubby caatinga, which is constituted by herbaceous, shrubby and arboreal plants that may reach up to 12 meters high.

Until 1997, this area belonged to a Siderurgy Industry (Itaminas S/A), which was authorized by the Brazilian environmental authorities (IBAMA) to extract coal through shallow wood cutting. From that year on, IBAMA discontinued Itaminas S/A permit for exploration purposes, and in 1999, the area was turned in a reserve as an environmental compensation for the coal exploration, which led to the creation of the FLONA Contendas do Sincorá. It is worth mentioning that the data collection of this study is grounded on 14 years of no-coal industrial activity in the area (BRASIL, 2006).

We sampled dung beetles in two NR areas, more than a kilometer apart each other, established on the management plan (BRASIL, 2006), which are defined as follows. (1) Natural Resources Management Zone (MZ): it is the closest area to the FLONA Main Office. According to the FLONA management plan, this zone has a higher flux of people due to administrative areas, which are near railways and motorways. (2) Preservation Zone (PZ): it is the zone where little or minimum human intervention has taken place and contains flora and fauna species and natural monuments which are relevant to scientific interests (BRASIL, 2006).

In each of the zones, three types of habitat, Riparian Forest (RF), Capoeira (CAP) and Arboreal Caatinga (ARB) were selected totaling six sampling sites. The capoeira habitat accounted for the caatinga areas whose logging industry took place 14 years ago and are nowadays at secondary succession (Fig. 1).

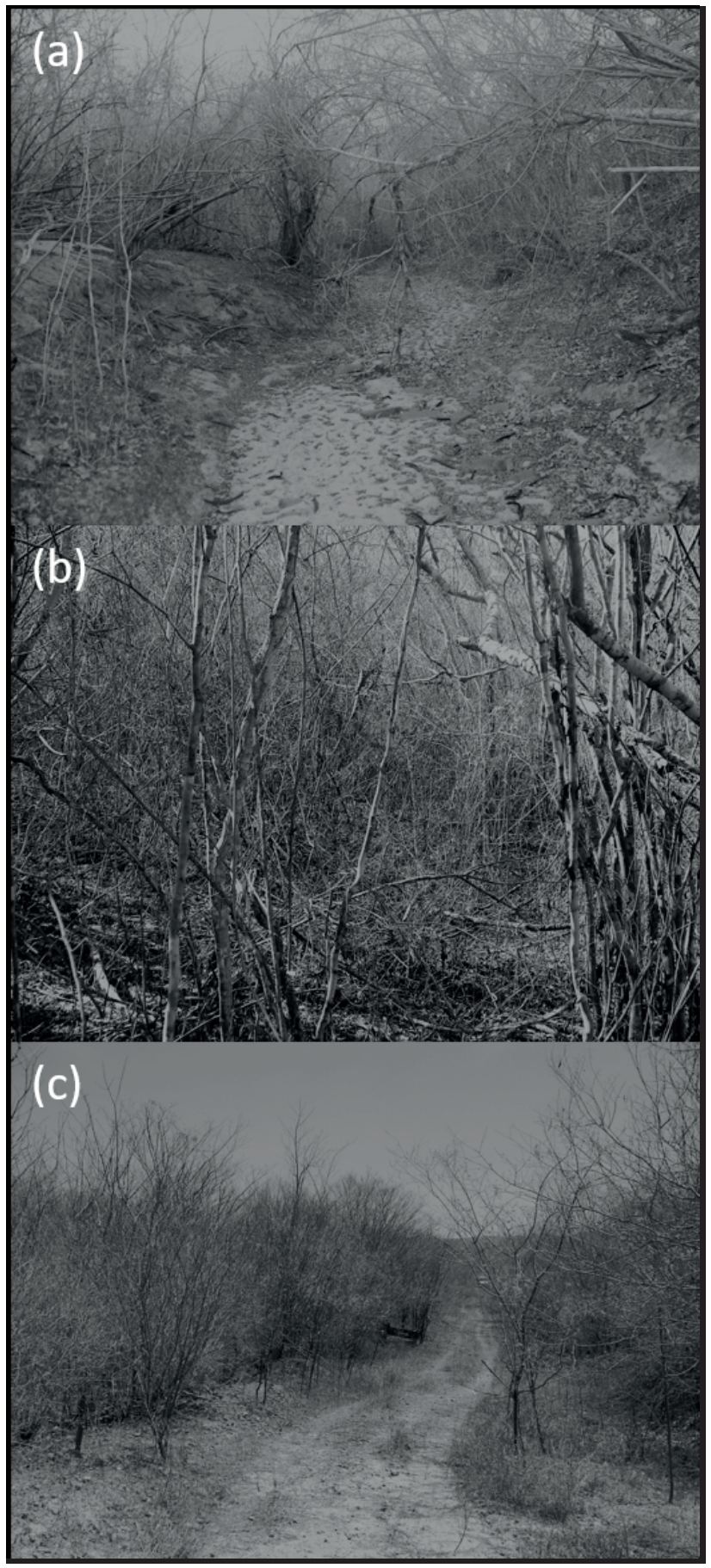

Fig. 1. Sampled habitats of FLONA Contendas do Sincorá, state of Bahia, Brazil during the dry season: a, Riparian Forest; b, Arboreal Caatinga; c, Capoeira.

Data collection. The data were collected during the dry and rainy season's two campaigns, in October 2010 and January 2011 respectively. In each site, five pitfall traps were placed $20 \mathrm{~m}$ apart from each other. Each trap was made using $12 \mathrm{~cm}$ diameter by $9 \mathrm{~cm}$ height plastic pots, filled with $250 \mathrm{ml}$ of alcohol (at 70\%) plus few drops of 
detergent, and covered with plastic plate sustained with wood sticks. A smaller recipient containing $50 \mathrm{~g}$ of human faeces as attractive bait was installed above the pitfall, to prevent beetles access the bait.

The traps remained in the sites for 24 hours in each campaign and transported later to the Laboratório de Ecologia e Conservação de Invertebrados of the Universidade Federal de Lavras (LECI/UFLA) where dung beetles were sorted, storedand identified by Dr. F. Silva (group taxonomist) in the lower taxonomic level possible. Vouchers of all species were deposited in the LECI and the Laboratório de Biologia da Conservação of Universidade Federal de São João delRei (LACON/UFSJ).

Data analysis. We built rank-abundance plots by the $\log 10+1$ of the abundance of the dung beetles communities of the MZ and PZ zones. The Scarabaeinae assemblages were contrasted under the following factors: zones (MZ or PZ) and habitat (RF, CAP or ARB).

Species accumulation curves were built to estimate the effort collection of dung beetles in the zones, through the estimative "Sobs" based on the captured individuals with extrapolation (COLWELl et al., 2012), selecting 100 randomizations (COLWELL, 2004).

Permutational multivariate analysis of variance (Permanova) was used to test these factors effects simultaneously. This is a statistical procedure which allows for testing the response of various factors in a multi-factorial experimental design based on distance measures through permutation methods and that do not assume data normality (ANDERSON, 2001).
We used multidimensional scaling method (MDS) (FAITH et al., 1987) for the samples ordination in a twodimensional graphic expressing the compositional similarity relationships between samples. The similarity matrix was calculated using Jaccard distance over a presence/absence dataset in order to retain only the information about community composition.

We used the indicator value (IndVal) (DUFRENE \& LEGENDRE, 1997) to describe the species indicator value for two management zones. This analysis is based on the relative frequency and abundance of species in each habitat and tested against the null hypothesis of no habitat association through randomization test. We included the species with six or more individuals.

\section{RESULTS}

A total of 1,214 individuals from 21 species were sampled (Tab. I). We collected more individuals in the $\mathrm{MZ}$ zone (746) contrasting to the PZ zone (468). The MZ has the highest observed richness (18) contrasted to PZ (17). The zones share 14 species of dung beetles (Tab. II).

The rank-abundance presented a very closely slope, but the species dominance in the communities and their position is replaced, except the most dominant, Canthon aff. piluliformes, which is the most abundant in both zones. The second most abundant species in the PZ, Deltochilum verruciferum, is ranked in the $8^{\text {th }}$ place in the MZ (Fig. 2). The species richness did not differ in both sampled zones (Fig. 3).

Tab. I. Dung beetles species and abundance of the FLONA Contendas do Sincorá, state of Bahia, Brazil collected by pitfall traps baited with human faeces in two zones of the management plan of the Natural Reserve (MZ, Management Zone; PZ, Preservation Zone). Dung beetles were sampled in the three main habitats inside the zones (ARB, Arboreal Caatinga; CAP, Caatinga in regeneration; RF, Riparian Forest).

\begin{tabular}{|c|c|c|c|c|c|}
\hline Species & $\mathrm{MZ}$ & $\mathrm{PZ}$ & ARB & CAP & RF \\
\hline Ateuchus semicribratus (Harold, 1868) & 26 & 26 & 18 & 17 & 17 \\
\hline Canthidium manni Arrow, 1913 & 3 & 0 & 1 & 1 & 1 \\
\hline Canthon aff. curvipes Harold, 1868 & 39 & 13 & 9 & 24 & 19 \\
\hline Canthon aff. piluliformis Blanchard, 1846 & 247 & 218 & 110 & 126 & 229 \\
\hline Canthon lituratus (Germar, 1813) & 2 & 0 & 0 & 1 & 1 \\
\hline Canthon sp. & 169 & 72 & 52 & 79 & 110 \\
\hline Canthon aff. substriatus Harold, 1868 & 5 & 8 & 8 & 0 & 5 \\
\hline Deltochilum aff. calcaratum Bates, 1870 & 28 & 5 & 15 & 13 & 5 \\
\hline Deltochilum verruciferum Felsche, 1911 & 17 & 83 & 18 & 24 & 58 \\
\hline Diabroctis mimas Linnaeus, 1758 & 1 & 0 & 1 & 0 & 0 \\
\hline Dichotomius irinus (Harold, 1867) & 69 & 0 & 30 & 34 & 5 \\
\hline Dichotomius puncticollis (Luederwaldt, 1935) & 6 & 12 & 5 & 5 & 8 \\
\hline Dichotomius aff. triangulariceps (Blanchard, 1846) & 3 & 1 & 1 & 1 & 2 \\
\hline Dichotomius geminatus (Arrow, 1913) & 4 & 3 & 2 & 2 & 3 \\
\hline Dichotomius nisus (Olivier, 1789) & 0 & 1 & 1 & 0 & 0 \\
\hline Digitonthophagus gazella (Fabricius, 1787) & 0 & 1 & 1 & 0 & 0 \\
\hline Malagoniella astyanax (Olivier, 1789) & 1 & 1 & 1 & 1 & 0 \\
\hline Ontherus digitatus Harold, 1868 & 1 & 4 & 0 & 3 & 2 \\
\hline Onthophagus aff. hirculus Mannerheim, 1829 & 1 & 1 & 0 & 1 & 1 \\
\hline Trichillum externepunctatum Preudhomme de Borre, 1880 & 0 & 10 & 2 & 5 & 3 \\
\hline Uroxys bahianus (Boucomont, 1927) & 124 & 9 & 25 & 53 & 55 \\
\hline Total abundance & 746 & 468 & 300 & 390 & 524 \\
\hline Species richness & 18 & 17 & 18 & 17 & 17 \\
\hline
\end{tabular}


Tab. II. Mean abundance per trap of dung beetle species indicators of habitat and zoning of the FLONA Contendas do Sincorá, state of Bahia, Brazil (RF, Riparian Forest; PZ, Preservation Zone; MZ, Management Zone) (p-values obtained by a randomization test with 999 resamplings).

\begin{tabular}{|c|c|c|c|c|}
\hline Species & $\begin{array}{c}\text { Indicator } \\
\text { of }\end{array}$ & $\begin{array}{c}\text { Mean } \\
\text { abundance }\end{array}$ & $\pm \mathrm{SD}$ & $\mathrm{p}$ value \\
\hline Canthon aff. curvipes Harold, 1868 & $\mathrm{MZ}$ & 25.2 & 4.98 & 0.029 \\
\hline Canthon aff. piluliformis Blanchard, 1846 & $\mathrm{RF}$ & 37.7 & 4.2 & 0.033 \\
\hline Deltochilum aff. calcaratum Bates, 1870 & $\mathrm{MZ}$ & 19.8 & 4.54 & $<0.01$ \\
\hline Deltochilum verruciferum Felsche, 1911 & $\mathrm{PZ} / \mathrm{RF}$ & $37.6 / 29.3$ & $5.38 / 5.48$ & $<0.01$ \\
\hline Dichotomius irinus (Harold, 1867) & MZ & 19.8 & 5.19 & $<0.01$ \\
\hline Trichillum externepunctatum Preudhomme de Borre, 1880 & $\mathrm{PZ}$ & 12.8 & 4.04 & $<0.01$ \\
\hline Uroxys bahianus (Boucomont, 1927) & $\mathrm{MZ}$ & 25.4 & 5.11 & $<0.01$ \\
\hline
\end{tabular}

The Scarabaeinae assemblages in the FLONA Contendas do Sincorá presented distinct composition in the NR zoning (Pseudo-F $=3.2774 ; \mathrm{p}<0.01$ ), but it is not explained by the habitat type into each zone (Pseudo-F $=$ $0.3536 ; p=0.712$ ) (Fig. 4).

Seven species are indicators of habitat (two in the $\mathrm{RF}$ ) or management zones (four in the $\mathrm{MZ}$ and two for PZ) (Tab. II).

\section{DISCUSSION}

The FLONA Contendas do Sincorá has dung beetles typical of the Caatinga biome, being essential to the maintenance of diversity around the Chapada Diamantina National Park (Lopes \& LouZAda, 2005; VieIra \& Silva, 2012). Our study tested the assumptions of the management plan that isolation could provide better conditions and resources for dung beetles. We found that $\mathrm{MZ}$ include sensitive Caatinga biome species, supporting a different community composition from areas where human activities are more frequent.

Higher dung beetles' species richness is expected with the increase in the environment heterogeneity and the level of habitat conservation (GARDNER et al., 2008). However, the types of habitat seem to offer the beetle's conditions to maintain a similar assemblage composition since the three habitats do not have a difference in assemblage structure. The capoeira habitat represents the areas under regeneration after the shallow woodcutting when the FLONA Contendas do Sincorá was still a private property used for the logging industry. These areas have been regenerating for 14 years, consequently, assuming the status of a secondary succession, a fact that holds appropriate elements to the Scarabaeinae assemblage in the arboreal caatinga and riparian forests.

Scarabaeinae assemblage structure bioindicates patterns of the vertebrate assemblages (EsTRADA et al., 1999). The exploration of zones in the FLONA, independent from the habitat to be managed, may alter the structure of vertebrate assemblages and, consequently, change other taxonomy groups such as Scarabaeinae. Both resources Management and Preservation zones are essential to the maintenance of the dung beetle assemblage structure. Hence, such species typical of the Caatinga biome can be excluded locally due to an inadequate management of these zones. Deltochilum verruciferum Felsche, 1911 is common in dry environments

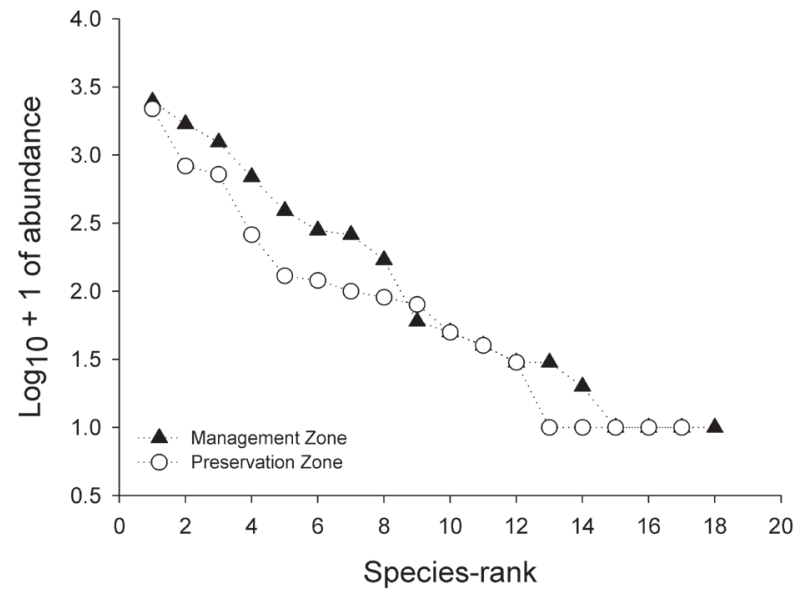

Fig. 2. Rank-abundance $\left(\log _{10}+1\right)$ of dung beetles species in two zones of the FLONA Contendas do Sincorá management plan, Management zone (MZ) and Preservation zone (PZ). Numbers indicate the species ranked in both zones: 1. Canthon aff. piluliformes; 2. Canthon sp.1; 3. Uroxys sp.; 4. Dichotomius irinus; 5. Canthon aff. curvipes; 6. Deltochilum aff. calcaratum; 7. Ateuchus sp.; 8. Deltochilum verruciferum; 9. Dichotomius aff. semianeus; 10. Trichillum externepunctatum.

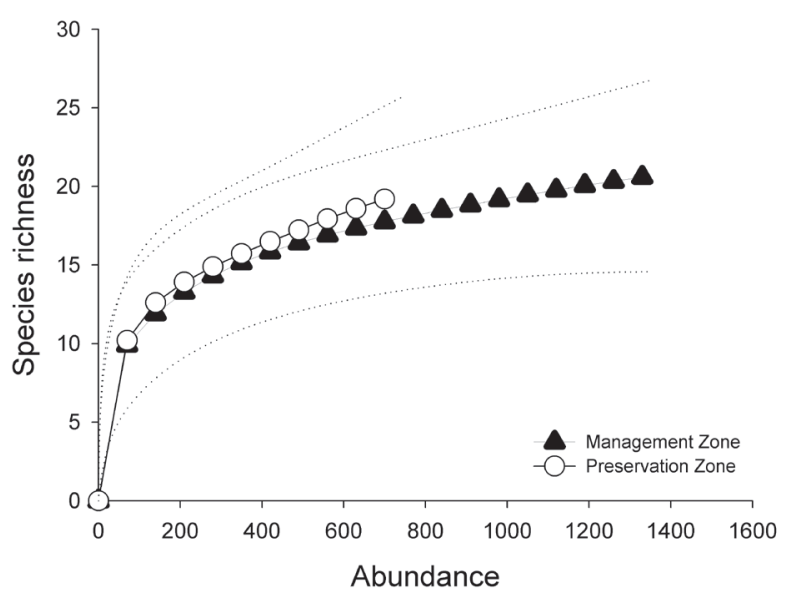

Fig. 3. Species richness accumulation curves for the Management zone and Natural resources zone stablished in the management plan of the FLONA Contendas do Sincorá conservation unit, state of Bahia, Brazil.

and was also registered in studies carried out in the Caatinga areas (LOPES \& LOUZADA, 2005; HERNÁNDEZ, 2007; LiBERAL et al., 2011; VieIRA \& Silva, 2012). The Deltochilum aff. calcaratum Bates, 1870 is a typical specie in dry-forests similar to the Cerrado, Caatinga and pastures (VIEIRA \& 


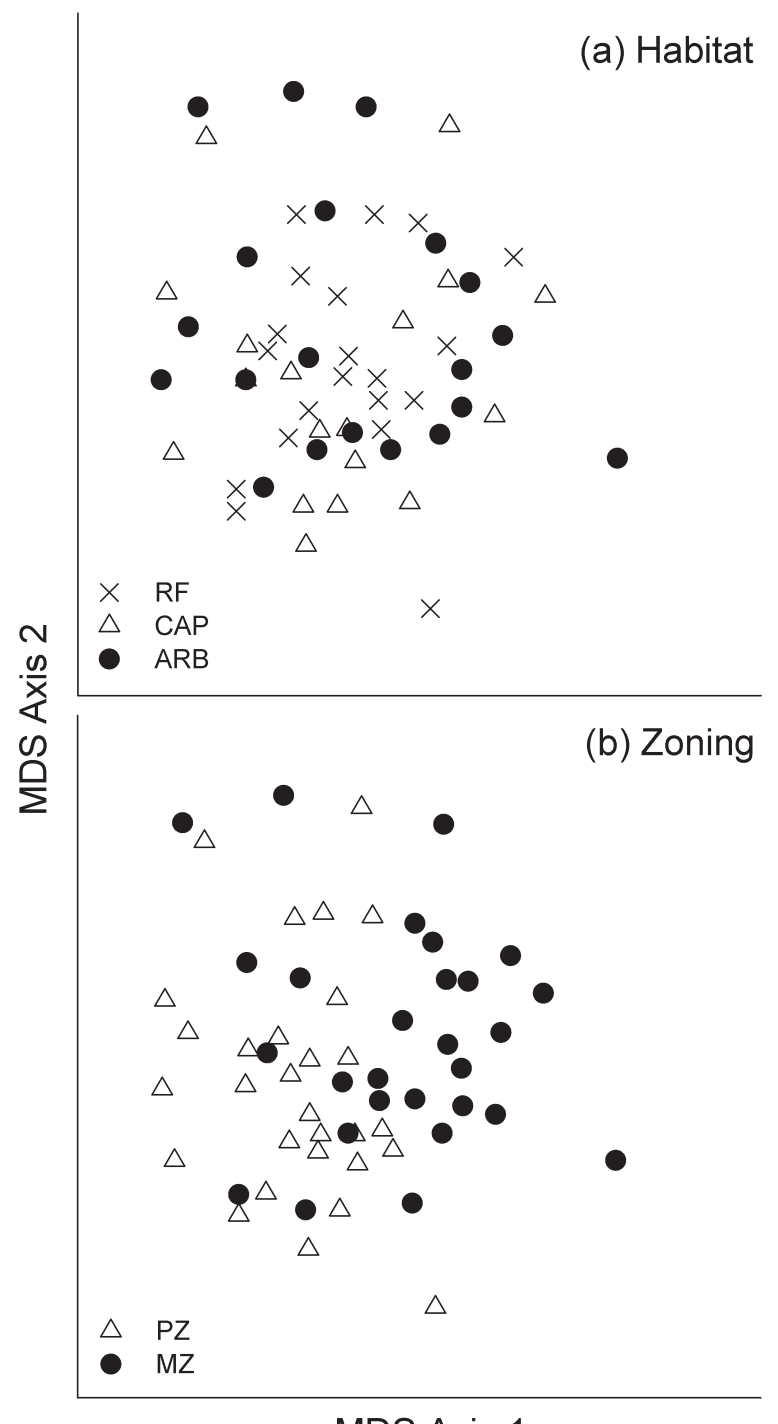

MDS Axis 1

Fig. 4. Multidimensional scaling (MDS) ordination of the dung beetle communities in: (a) Riparian Forest (RF), Capoeira (CAP) and Arboreal Caatinga (ARB); (b) Management (MZ) and Preservation Zone (PZ) of the Brazilian National Reserve FLONA Contendas do Sincorá, state of Bahia.

SiLvA, 2012). Both species are indicators of management (D. calcaratum) and preservation (D. verruciferum) zones which mean that their presence should be considered.

Finally, the FLONA Contendas do Sincorá is a relevant area to the conservation of the Caatinga Scarabaeinae fauna as it holds together elements that are exclusive of this particular biome. The zoning planned for this NR, in fact, hold two different assemblages that need particular attention when updates in management plan take place. Also, this NR is located geographically next to the Chapada Diamantina, which keeps other Scarabaeinae species (LOPES \& LOUZADA, 2005) and contributes, in a broader spatial scale, to the maintenance of the Scarabaeinae regional diversity.
Acknowledgments. We would like to thank Marllon de Oliveira Dutra, Dra. Michele Martins Correa, Dr. Paulo Sávio Damásio da Silva and Sr. Antonio Correia Freire for the support with the data collection; Bárbara Mourão for the support with the material selection; the FLONA Board for granting us access to the collection area and provide us with the technical and logistic support in the field research.

\section{REFERENCES}

Anderson, M. J. 2001. A new method for non-parametric multivariate analysis of variance. Austral Ecology 26:32-46.

Barbero, E.; Palestrini, C. \& Rolando, A. 1999. Dung beetle conservation: effects of habitat and resource selection (Coleoptera: Scarabaeoidea). Journal of Insect Conservation 3(2):75-84.

Brasil. 2006. Plano de Manejo Floresta Nacional Contendas do Sincorá. Vol. II. Brasília, IBAMA - Instituto Brasileiro de Meio Ambiente e Recursos Naturais Renováveis. Available at <http://www.icmbio. gov.br/portal/unidadesdeconservacao/biomas-brasileiros/caatinga/ unidades-de-conservacao-caatinga/2123-flona-contendas-do-sincora $>$. Accessed on 15 November 2016.

Colwell, R. K.; MaO, C. X. \& Chang, J. 2004. Interpolating, extrapolating, and comparing Incidence-based species accumulation curves. Ecology (85):2717-2727.

Colwell, R. K.; Chao, N. J.; Gotelli, S.-Y.; Lin, C. X.; MaO, R. L.; Chazdon, R. \& Longino, J. T. 2012. Models and estimators linking individual-based and sample-based rarefaction, extrapolation, and comparison of assemblages. Journal of Plant Ecology 5(1):3-21.

DAVIS, A. L. V. 2002. Dung beetle diversity in South Africa: influential factors, conservation status, data inadequacies and survey design. African Entomology 10(1):53-65.

Dufrene, M. \& Legendre, P. 1997. Species assemblages and indicator species: the need for a flexible asymmetrical approach. Ecological Monographs 67(3):345-366.

Estrada, A.; Anzures, A. \& Coates-Estrada, R. 1999. Tropical rain forest fragmentation, Howler Monkeys (Alouatta palliata) and Dung Beetles at Los Tuxtlas, Mexico. American Journal of Primatology 48(4):253-262

FAith, D. P.; Minchin, P. R. \& Belbin, L. 1987. Compositional dissimilarity as a robust measure of ecological distance. Vegetagio 69(1-3):57-68.

Gardner, T. A.; Hernández, M. I. M.; Barlow, J. \& Perez, C. A. 2008. Understanding the biodiversity consequences of habitat change: the value of secondary and plantation forests. Journal of Applied Ecology 45(3):883-893.

Gries, R.; Louzada, J.; Almeida, S.; Macedo, R. \& Barlow, J. 2012. Evaluating the impacts and conservation value of exotic and native tree afforestation in Cerrado grasslands using dung beetles. Insect Conservation and Diversity 5(3):175-185.

Halffter, G. \& Favila, M. E. 1993. The Scarabaeinae (Insecta: Coleoptera) an animal group for analysing, inventorying and monitoring biodiversity in tropical rainforest and modified landscapes. Biology International 27:15-21.

Hernández, M. I. M. 2007. Besouros escarabeíneos (Coleoptera: Scarabaeidae) da caatinga paraibana, Brasil. Oecologia Brasiliensis 11(3):356-364.

Leal, I. R.; Da Silva, J. M. C.; Tabarelli, M. \& Lacher JR., T. E. 2005. Mudando o curso da conservação da biodiversidade na Caatinga do Nordeste do Brasil. Megadiversidade 1(1):139-146.

Liberal, C. N.; Farias, A. M. I.; Meiado, M. V.; Filgueiras, B. K. C. \& IANNUZZI, L. 2011. How habitat change and rainfall affect dung beetle diversity in Caatinga, a Brazilian semi-arid ecosystem. Journal of Insect Science 11(1): 1-11.

Lopes, P. P. \& LouzadA, J. N. C. 2005. Besouros (Scarabaeidae e Histeridae). In: JuncÁ, F.A.; Funch, L. \& RochA, W. orgs. Biodiversidade e Conservação da Chapada Diamantina. Brasília, Ministério do Meio Ambiente, p. 284-298.

MMA. 2016. Ministério do Meio Ambiente. Available at $<$ http://www. mma.gov.br/biomas/caatinga/>. Accessed on 15 November 2016. 
Ramos, M. A. \& Albugueroue, U. P. 2012. The domestic use of firewood in rural communities of the Caatinga: How seasonality interferes with patterns of firewood collection. Biomass and Bioenergy 39:147-158.

SAmpaio, Y. \& Batista, J. E. M. 2004. Desenvolvimento regional e pressões antrópicas no bioma Caatinga. In: Silva, J. M. C.; Tabarelli, M.; FonseCA, M. T. \& LINS, L.V. org. Biodiversidade da Caatinga: áreas e ações prioritárias para a conservação. Brasília, Ministério do Meio Ambiente, p. 311-324.

Silva, J. M. C.; Tabarelli, M.; Fonseca, M. T. \& Lins, L. V. 2004. Biodiversidade da Caatinga: áreas e ações prioritárias para a conservação. Brasília, Ministério do Meio Ambiente. 382p.
SNUC. 2000. Sistema Nacional de Unidades de Conservação. Lei Federal $\mathrm{n}^{\circ}$ 9.985. Available at $<$ http://www.planalto.gov.br/ccivil_03/leis/L9985. htm>. Accessed on 12 May 2017.

van Rensburg, B. J.; McGeoch, M. A.; Chown, S. L. \& van JaArsveld, A. S. 1999. Conservation of heterogeneity among dung beetles in the Maputaland centre of endemism, South Africa. Biological Conservation 88:145-153.

VieIRA, L. \& Silva, F. A. B. 2012. Dung beetle (Coleoptera: Scarabaeidae: Scarabaeinae) of the Floresta Nacional Contendas do Sincorá, Bahia, Brazil. Checklist 8(4):733-739. 